\title{
Review of Seismic Characteristics in Erbil City, the Capital of the Kurdistan Region of Iraq
}

\author{
Zina A. Abdul Jaleel*, Bahman O. Taha \\ Department of Technical Civil Engineering, Erbil Polytechnic University, Erbil, Kurdistan Region, Iraq
}

*Corresponding author:

Zina A. Abdul Jaleel

E-mail: zina.abduljaleel@

epu.edu.iq

Received: 01 August 2019

Accepted: 03 September 2019

Published: 01 December 2019

DOI

10.25156/pti.v9n2y2019.pp161-170

\section{A B S T R A C T}

Erbil city essentially suffers from the risk of earthquakes generated by Zagros-Taurus Belt. The central objective of this study is to identify the seismic characteristics and required seismic parameters for structural analysis. The methodology concentrated on reviewing the seismology and geology of Erbil city. It was concluded that the tectonically classified by an outer platform of the low folded zone in the position of Western Zagros Fold-Thrust Belt of the Arabian plate, geologically covered by Quaternary sediments and lithologically described by fluvial sediments, and the dynamic soil properties classified by site Class D. Seismicity review indicated that the seismic source is characterized by strike-slip (normal) fault and majority events exhibit at the shallow crustal with expected moment magnitude between 6 and 7.5. It was observed that the peak ground acceleration (PGA) has been updated, especially after the last cyclic earthquake in the region. The summary of the previous seismic hazard indicates that the PGA according to the World Health Organization, Global Seismic Hazard Assessment Program, and Uniform building code is identified by the value higher than $0.3 \mathrm{~g}$ for 475 years return period, while according to national probabilistic seismic hazard analysis studies in Iraq and Arabian Peninsula is identified by $0.4 \mathrm{~g}$ for $2 \%$ probability of exceedance in 50 years ( 2475 years return period), and estimated PGA to be $0.25 \mathrm{~g}$ for $10 \%$ likelihood of exceedance in 50 years ( 475 years return period), in a term of $5 \%$ damped at bedrock condition. Proposed spectral acceleration (Sa) in Erbil city at 0.2 and $1.0 \mathrm{~s}$ evaluated to be $1.0 \mathrm{~g}$ and $0.53 \mathrm{~g}$, for the site Class D and compared with Sa in the literature.

Keywords: Geology; Hazard; Peak ground acceleration; Seismic; Spectral acceleration

\section{INTRODUCTION}

Erbil city located at the north corner of the Arabian plate, geologically bounded by Zagros-Taurus Belt [Figure 1], and tectonically characterized by a complex tectonic structure, where the Arabian plate is subducted under the Eurasian plate, indicated as a seismically active belt (Abdulnaby et al., 2014b; Ghalib and Aleqabi, 2016).

According to historical record for the period (1971-2011) Erbil governorate experienced 195 small and moderate earthquakes, especially, one of the significant moderate events is recorded on July 24, 1991, with the moderate magnitude of Mw 5.5 and focal depth of $26 \mathrm{~km}$, near Erbil city by $37.2 \mathrm{~km}$ (IMOS, 2018). Consequently, Alakaam and Hussain (2016) specified three levels of risk in Erbil governorate namely, low risk (1-3), medium risk (3-4), and high risk $(>4)$ forming 64,32 , and $4 \%$ of the total area, respectively, as depicted in Figure 2. More recently, the activity of the Zagros fault has been increased significantly. Particularly, powerful earthquakes with $\mathrm{Mw} 7.3,6.3$, and about 6 in November 2017 (USGS, 2017), November 2018 (EMSC, 2018), and January 2019 (EMSC, 2019) were recorded, respectively, at the shallow depth. However, the initiated point was far from the city but noticed in Erbil city. Therefore, the last cyclic earthquakes have raised many questions about the seismic characteristics of Erbil city. For this purpose, seismology and geology of Erbil city reviewed to identify the seismic characteristics and seismic parameters required for structural analysis.

\section{GEOLOGY AND TECTONIC SETTING OF ERBIL CITY}

Kurdistan Region (KR) is characterized by the portion of the convergent plate boundary, where the Arabian plate subducts northward below the Eurasian plate (Iranian and Turkish plateaus) as shown in Figure 1. The collisionsubduction zone between these two plates is mainly dictated by the Bitlis-Zagros Fold and Thrust Belts. As a result, this belt is one of the most seismically active regions that perform the majority of earthquakes (Abdulnaby et al., 2014b; Ghalib and Aleqabi, 2016).

At the tectonic level, Erbil city is assorted by the outer platform of the Arabian plate, characterized by the confused 
part of Western Zagros Fold-Thrust Belt (WZFTB), and covered by low folded zone (LFZ) (Foothill), represented in Figure 3 (Fouad, 2015).

According to the geological formation and lithological description, Erbil city covered by Quaternary sediments is represented by polygenetic accumulation fluvial sediments (Fouad and Sissakian, 2015). Further, the

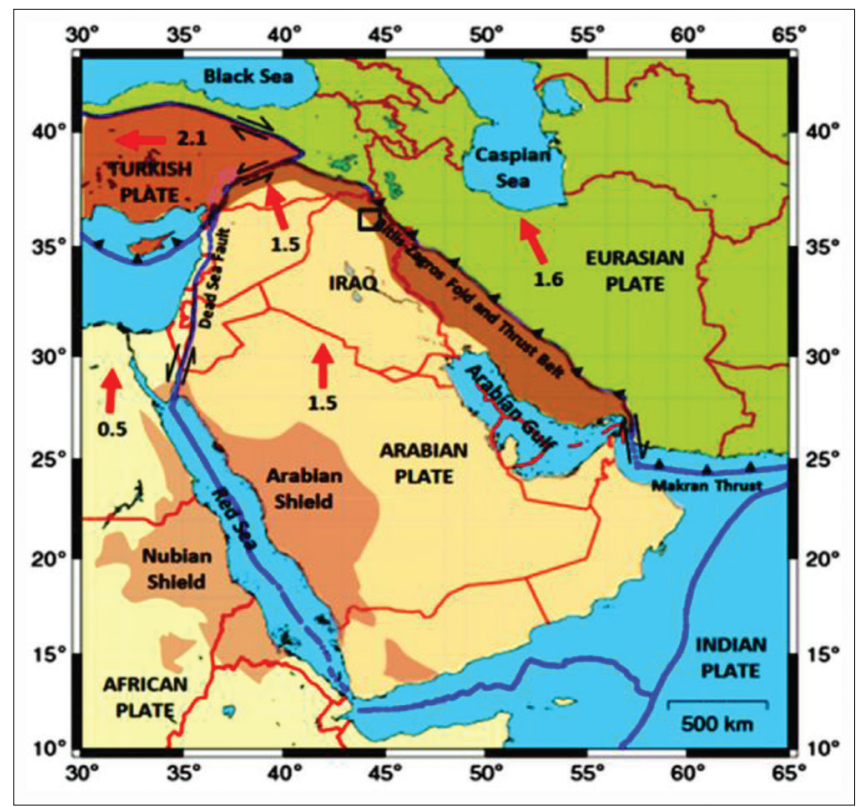

Figure 1: Tectonic map of Arabian and Eurasian plate (Abdulnaby et al., 2014b)

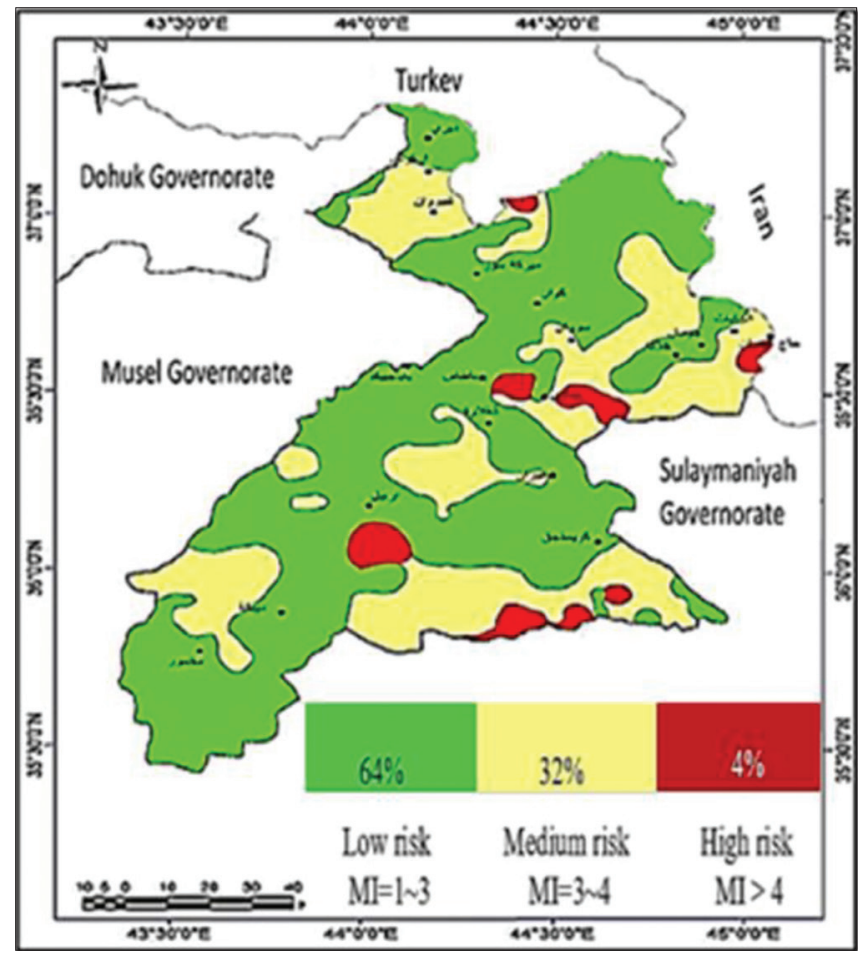

Figure 2: Seismic hazard map of Erbil province for the historical record (1971-2011) (Alakaam and Hussain, 2016) effect of geological structure in the topic of the seismic risk recognized by site effect. According to the database of the dynamic soil properties, the average compression wave velocities ranged from 687 to $1460 \mathrm{~m} / \mathrm{s}$, based on the code of practice, the Erbil site classified by soil site Class D, the database collected from the soil investigation

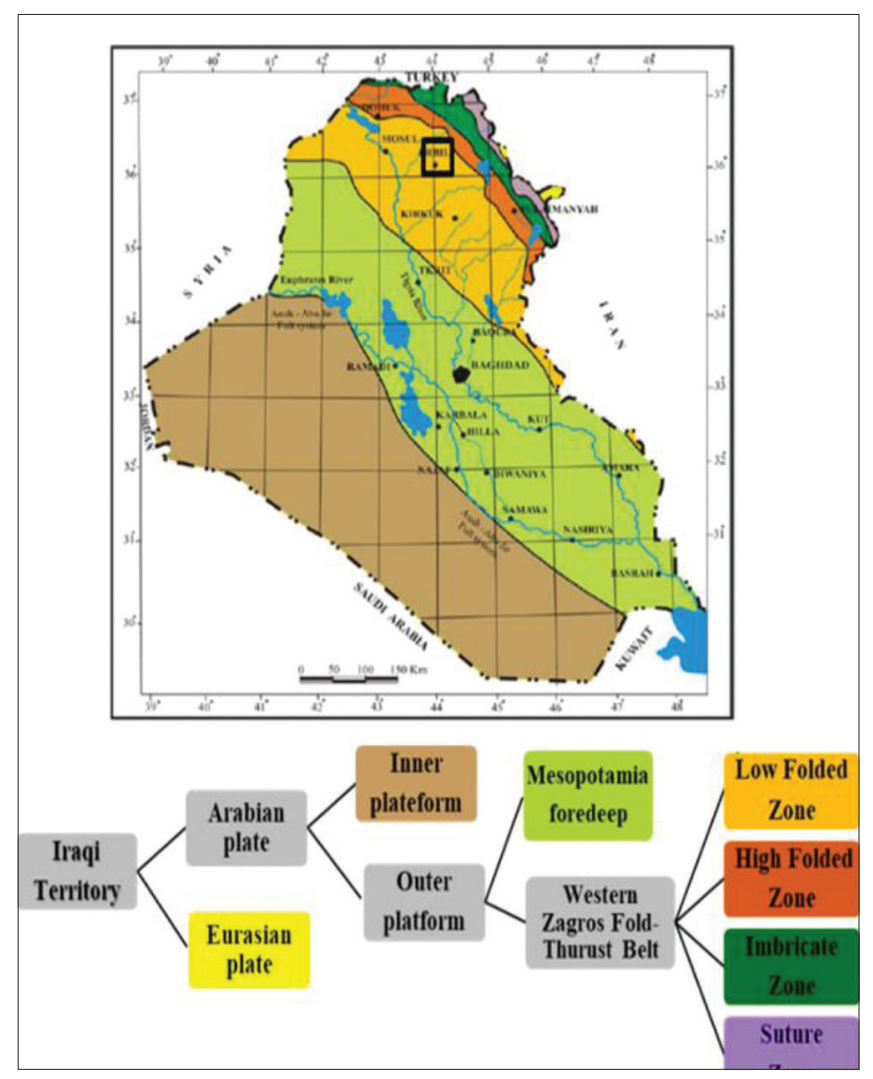

Figure 3: Tectonic divisions of Iraq (Fouad, 2015)

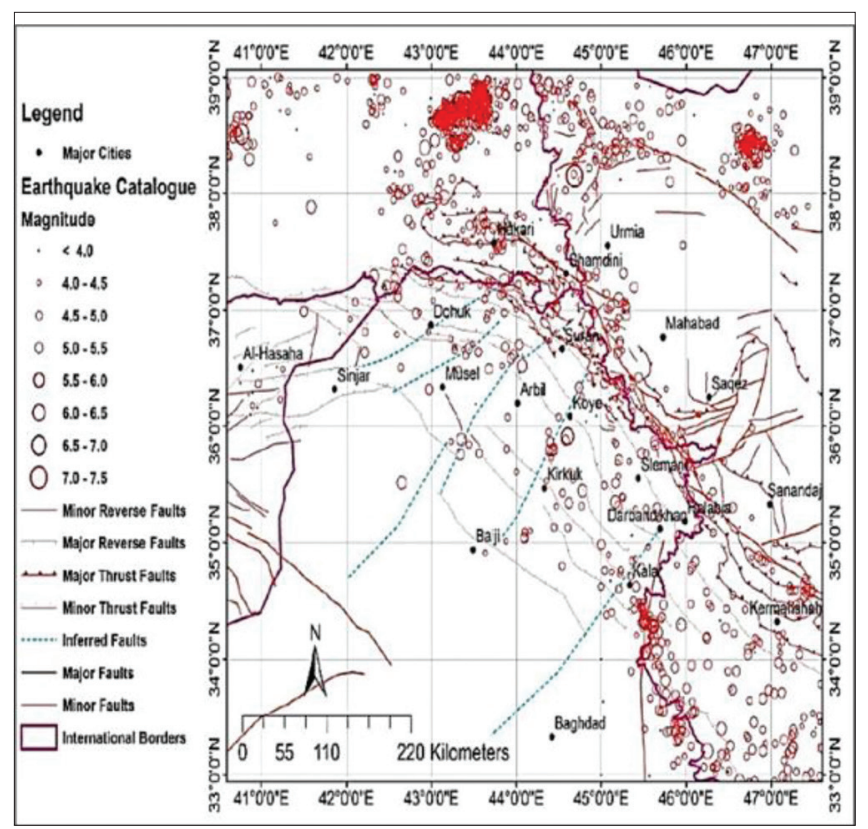

Figure 4: Seismicity map of Kurdistan Region (Hosseini et al., 2014a) 
report from the important project in the city, which was prepared by Mohammed and Abdulrassol (Mohammed and Abdulrassol, 2017).

\section{SEISMICITY AND SEISMIC SOURCE CHARACTERISTICS OF ERBIL CITY}

Seismicity relates to the geographic and historical occurrence of earthquakes which are the main step to identify the seismic hazard of an area. Figure 4 represents the seismotectonic regions, seismicity, and major faults for KR proposed by Hosseini et al. (Hosseini et al., 2014a). Erbil city usually suffers from the possibility of the Zagros

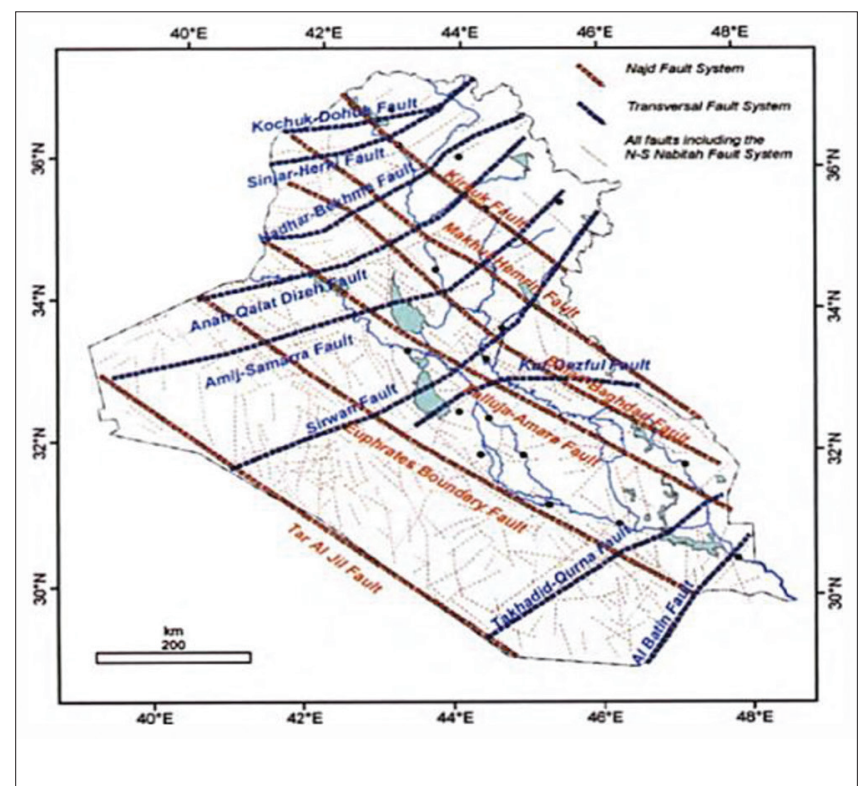

Figure 5: Distribution of faults near Erbil city (Jassim and Goff, 2006)
Fold-Thrust Belt. In addition, there are also extensional activities in the region along faults, Figure 5 is distinct examples of these faults near the city. Kirkuk fault (system of NW-SE Najd), Hadhar-Bekhme, and Anah-Qalat Dizeh fault (system of NE-SW/E-W Transverse), and (system of N-S Nabitah) (Jassim and Goff, 2006), the common stress pattern defined by strike-slip (normal) faulting (Abdulnaby et al., 2014a).

In the literature, the seismicity of the north corner of the Arabian plate, which involves Erbil city, was studied by various authors. Alsinawi and Al-Qasrani evaluated isointensity value before and after $1900 \mathrm{AD}$, based on Modified Mercalli classified by MM=VIII and MM=V, respectively, and assessed seismicity index by 0.3 with $\mathrm{Mb}$ $>4$ every 2-5 years, as shown in Figure 6 (Al-Sinawi, 2006).

Subsequently, Ameer et al. (2005), Raza Hosseini et al. (2014a), Onur et al. (2016), Said and Farman (2018a; 2018b), and El-Hussain et al. (2018) evaluated the active parameters regarding the location of faults and past earthquakes inside the Arabian plate. Table 1 summarizes the active parameters, which was identified in Erbil city, such as the constant parameters to find earthquake recurrence in the expression of Gutenberg Richter Law (GR) (logN_m=a - b.m).

Where $\mathrm{Nm}$ is the annual rate of earthquakes with magnitudes greater than $\mathrm{m}$.

$\mathrm{a}$ and $\mathrm{b}$ are constants to be obtained by regression of past earthquakes data with reveal the seismicity of study area. Completeness magnitude (Mc), and maximum expected and observed earthquake magnitude, the active parameters were studied with respect to earthquake data time span,

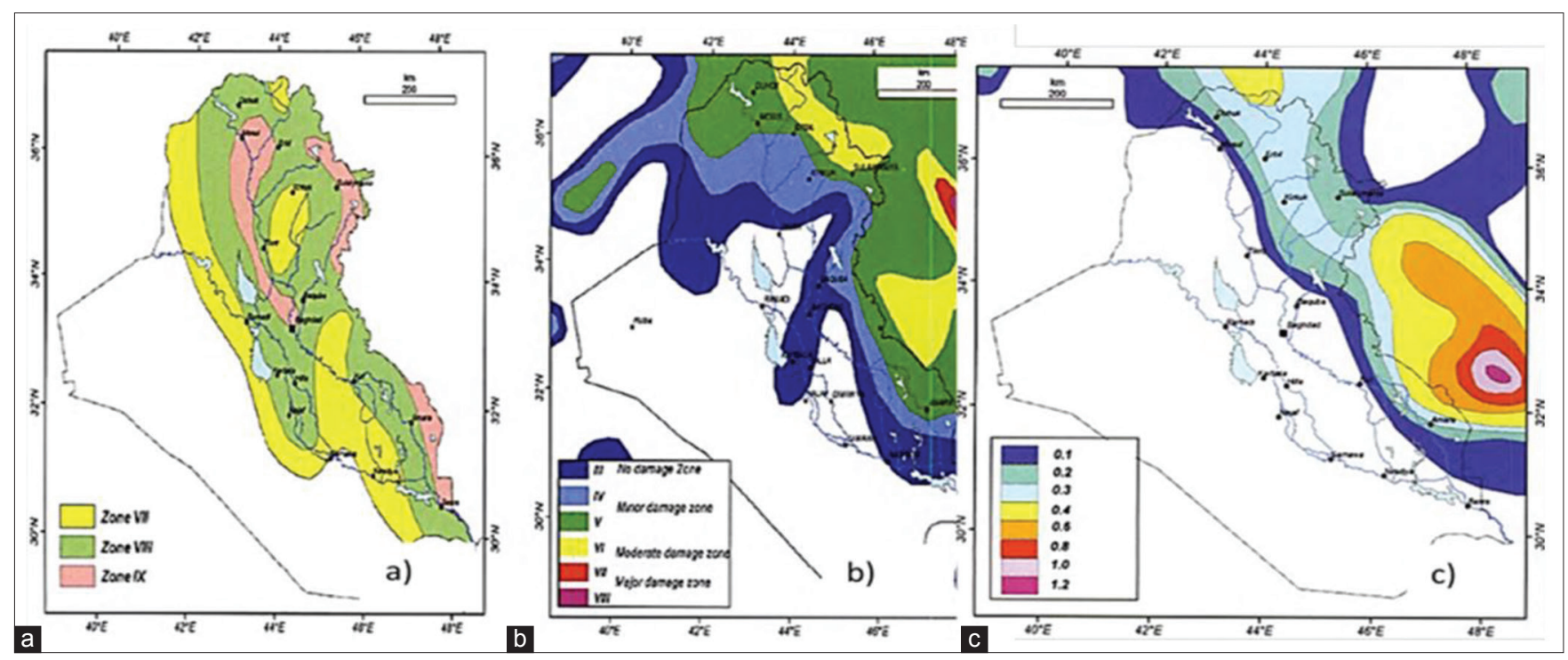

Figure 6: Seismic isointensity maps of Iraq for historical period (a) before 1900, (b) after 1900, and (c) seismicity index map (Al-Sinawi, 2006) 
Table 1: Seismic active parameters for Erbil seismicity adopted by various authors

\begin{tabular}{|c|c|c|c|c|c|c|}
\hline $\begin{array}{l}\text { Reference } \\
\text { study }\end{array}$ & $\begin{array}{l}\text { Ameer et al. } \\
(2005)\end{array}$ & $\begin{array}{l}\text { Hosseini et al. } \\
\text { (2014a) }\end{array}$ & $\begin{array}{l}\text { Onur et al. } \\
(2016)\end{array}$ & $\begin{array}{l}\text { Said and Farman } \\
\text { (2018a) }\end{array}$ & $\begin{array}{l}\text { Said and Farman } \\
\text { (2018b) }\end{array}$ & $\begin{array}{l}\text { El-Hussain } \\
\text { et al. (2018) }\end{array}$ \\
\hline $\begin{array}{l}\text { Earthquake } \\
\text { data time span }\end{array}$ & $\begin{array}{l}1905-2000 \\
M s>5.2\end{array}$ & $\begin{array}{l}1900-2014 \\
M>4\end{array}$ & $\begin{array}{l}1900-2009 \\
M w>4\end{array}$ & $\begin{array}{l}\text { 1900-Up-April } \\
2016 \\
\text { Mw>4 }\end{array}$ & $\begin{array}{l}\text { 1900-Up- } \\
\text { December } 2017 \\
\text { Mw>4 }\end{array}$ & $\begin{array}{l}1900-2015 \\
M w>4\end{array}$ \\
\hline Study location & $\begin{array}{l}\text { Iraq Region } \\
\text { (R.). (29- } \\
38.5) \mathrm{N} \text { and } \\
(39-50) \mathrm{E}\end{array}$ & $\begin{array}{l}\text { Kurdistan R. } \\
(33.5-39.5) \mathrm{N} \\
\text { and }(40.5-47.5) \mathrm{E}\end{array}$ & $\begin{array}{l}\text { Iraq R. }(26-40) \mathrm{N} \\
\text { and }(36-51) \mathrm{E}\end{array}$ & $\begin{array}{l}\text { Iraq R. }(26-40) \mathrm{N} \\
\text { and }(36-51) \mathrm{E}\end{array}$ & $\begin{array}{l}\text { Iraq R. }(26-40) \mathrm{N} \\
\text { and }(36-51) \mathrm{E}\end{array}$ & $\begin{array}{l}\text { Arabian plate } \\
(10-40) \mathrm{N} \text { and } \\
(30-65) \mathrm{E}\end{array}$ \\
\hline $\begin{array}{l}\text { Earthquake } \\
\text { source data }\end{array}$ & $\begin{array}{l}\text { PDE, BSO, } \\
\text { Fahmi and } \\
\text { Alabbasi } 89\end{array}$ & $\begin{array}{l}\text { ISC, USGS/NEIC, } \\
\text { IEES, EMEC, } \\
\text { NEMT }\end{array}$ & $\begin{array}{l}\text { ISC, EMSC, } \\
\text { USGS, GCMT, } \\
\text { Ambraseys }\end{array}$ & $\begin{array}{l}\text { C88, IIEES, } \\
\text { AFDA, GCMT }\end{array}$ & $\begin{array}{l}\text { C88, IIEES, } \\
\text { AFDA, GCMT }\end{array}$ & $\begin{array}{l}\text { Compiled Deif } \\
\text { et al. (2017) }\end{array}$ \\
\hline $\begin{array}{l}\text { Number of } \\
\text { events }\end{array}$ & $\begin{array}{l}1000 \\
\text { dependent } \\
\text { events }\end{array}$ & $\begin{array}{l}\text { Independent } \\
\text { events }\end{array}$ & $\begin{array}{l}4000 \text { dependent } \\
\text { events }\end{array}$ & $\begin{array}{l}3519 \text { independent } \\
\text { events }\end{array}$ & $\begin{array}{l}4300 \text { independent } \\
\text { events }\end{array}$ & - \\
\hline $\begin{array}{l}\text { Zone } \\
\text { description } \\
\text { [Figure 7] }\end{array}$ & St.P.4 (a) & Zone 4 (b) & $\begin{array}{l}\text { Zone } 2 \text { unstable } \\
\text { shelf-A (c) }\end{array}$ & Zone 2 (d) & Zone 2 (e) & $\begin{array}{l}\text { Kirkuk- } \\
\text { embayment (22) } \\
\text { (f) or Zagros } \\
\text { simple fold ( } 7 \text { ) (g) }\end{array}$ \\
\hline Mmin & 4 & 4 & 4.4 & 4.3 & 4.3 & 4 \\
\hline Mc & 4 & $\underline{-}$ & 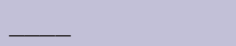 & 4.4 & 4.4 & 4 \\
\hline GR: a-value & $\underline{ }$ & $4.19 \pm 0.665$ & 5.3674 & 4.358 & 4.9485 & 2.93 or (4.27) \\
\hline GR: b-value & $0.49 \pm 0.19$ & $0.71 \pm 0.05$ & 1.1996 & 1.0857 & 1.1835 & 0.73 or $(0.82)$ \\
\hline $\begin{array}{l}\text { Max. expected } \\
\text { magnitude }\end{array}$ & $5.85 \pm 0.35$ & $6.8 \pm 0.31$ & 7.6 & 7.72 & 7.5 & 6.6 or $(6.9)$ \\
\hline $\begin{array}{l}\text { Max. observed } \\
\text { magnitude }\end{array}$ & 5.7 & 6.2 & 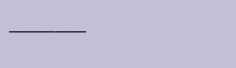 & $\begin{array}{l}\text { 7.3 November } \\
2017\end{array}$ & $\begin{array}{l}7.312 \text { November } \\
2017\end{array}$ & 6.5 or $(6.8)$ \\
\hline
\end{tabular}

earthquake source data, and a number of (dependent/ independent) events. Figure 7 represents the location of the past earthquakes and the source zone described by authors. Based on the seismicity review, the occurrence of destructive earthquakes in the study area is highly anticipated in the future. The maximum expected earthquake magnitude in Erbil city can be identified between Mw 6 and 7.5 at the shallow crustal have a depth of $0-35 \mathrm{~km}$.

\section{PREVIOUS HAZARD ASSESSMNET STUDIES}

Seismic hazard analysis (SHA) is the process of predicting strong ground motions for a specific site. The hazard is best represented as strong ground shaking, especially in the earthquake loss assessment. In general, in the seismic hazard assessments, the scientists use two basic methods of SHA:

1. Deterministic SHA (DSHA)

2. Probabilistic SHA (PSHA).

The process of PSHA is taking advantage of taking into the calculation of the most uncertainties involved with seismic hazard SHA (Kramer, 1996). In previous codes of practice, the seismic hazard defined by $Z$ factor is applied to describe the peak parameters of ground motion acceleration.

According to the Iraqi seismic design Code (1988), Erbil city located within zone 4 that the seismic zone factors
$(\mathrm{Z}=0.8)$ and peak ground accelerations (PGAs) ranging from $0.07 \mathrm{~g}$ to $0.125 \mathrm{~g}$ for 500 return period.

However, Iraqi seismic building Code, 1997 (Code 2/1997, 1997) classified Erbil city as Zone $2(Z=0.07)$. Contrary to the uniform building Code (UBC) (1997), Erbil city can be categorized as a Zone 3 and $\mathrm{Z}$ factor ranged between 0.2 and 0.3. The seismic hazard maps created by Iraqi seismic Mahmood et al. (1988) and (1997) are shown in Figure 8. Consequently, seismic hazard maps generated by the Global Seismic Hazard Assessment Program (GSHAP) (Grünthal et al., 1999) and World Health Organization (WHO, 2010) demonstrates seismic hazard in Erbil city, in a term of PGA vary from 2.4 to $4 \mathrm{~m} / \mathrm{s}^{2}(0.24 \mathrm{~g}$ to $0.4 \mathrm{~g})$ for a 475 year return period as shown in Figure 9.

Al-Sinawi and Al-Qasrani estimated that PGA in Erbil city to be ranging between 0.5 and $0.6 \mathrm{~g}$ for a 100 -year return period [Figure 10] (Al-Sinawi, 2006).

Yaseen et al. (2014) proposed PGA varying between 0.25 and $0.4 \mathrm{~g}$ for Erbil city on bedrock.

After Yaseen et al., the authors conducted a PSHA in terms of PGA, and 5\% damped at bedrock condition, Hosseini et al. (2014b) estimated the PGA [Figure 11] in Erbil city ranging from $0.24 \mathrm{~g}$ to $0.26 \mathrm{~g}$ for the 475 years return period. 


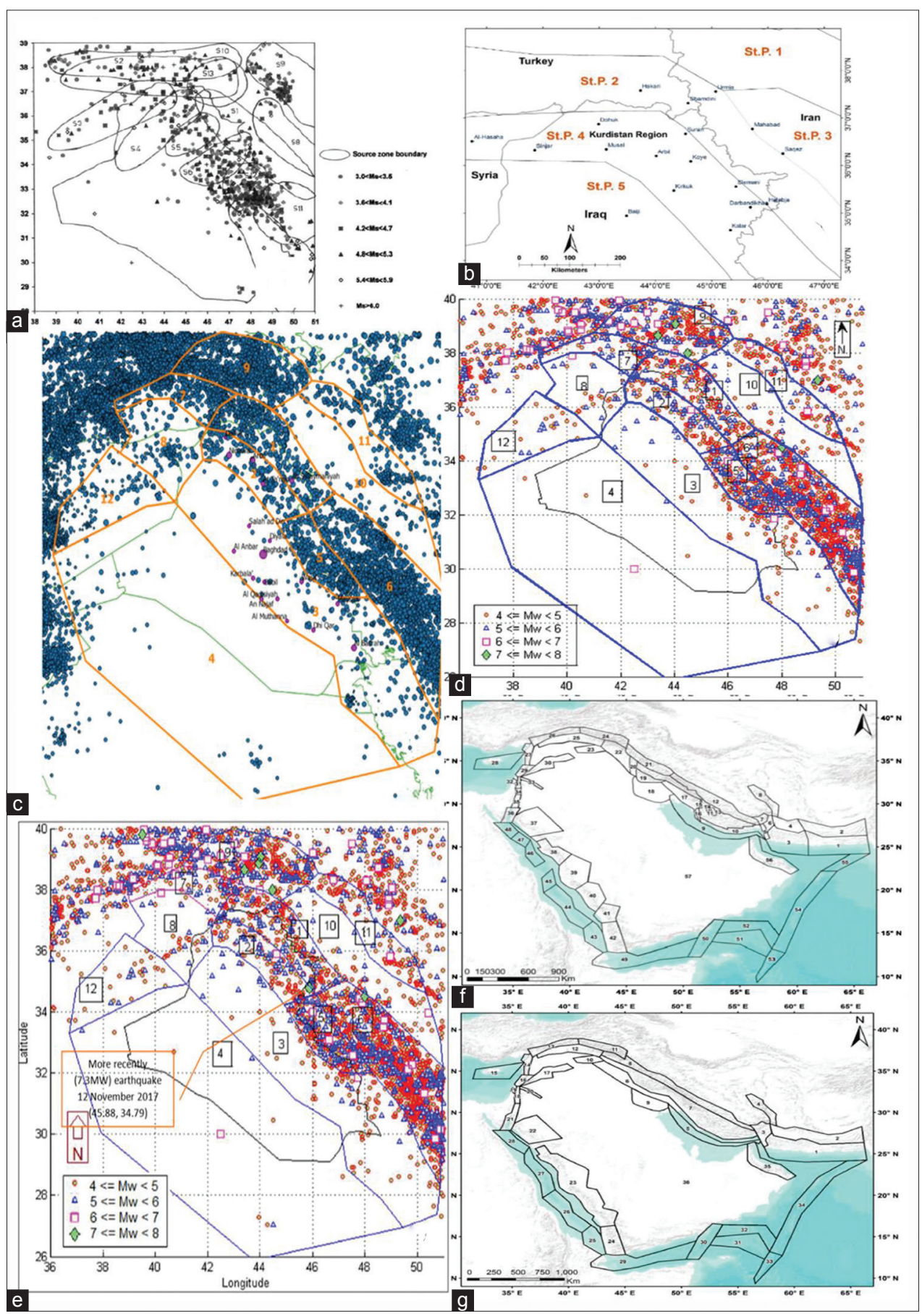

Figure 7: Seismicity model with zone description prepared by (a) Ameer et al. (Ameer et al., 2005), (b) Hosseini et al. (Hosseini et al., 2014b), (c) Onur et al. (Onur et al., 2016), (d and e) Said and Farman for Iraqi map (Said and Farman, 2018a; 2018b), and (f and g) El-Hussain et al. for Arabian plate (El-Hussain et al., 2018)

Onur et al. (2016) assessed PGA [Figure 12] in Erbil city with $0.2-0.25 \mathrm{~g}$ for the return period of 475 and with $0.35-0.4 \mathrm{~g}$ for the return period of 2475 . It is deserving to consider this study to be the basis for the Draft of Iraqi Seismic Code (Draft/Code-16, 2016).

Said and Farman evaluated PGA (2018a), in Erbil city, ranged between $0.3 \mathrm{~g}$ and $0.4 \mathrm{~g}$ for a 2475 return period, and also they updated PGA (2018b), the value extended between $0.2 \mathrm{~g}$ and $0.25 \mathrm{~g}$, and $0.4 \mathrm{~g}$ and $0.45 \mathrm{~g}$ for return period of 475 and 2475, respectively [Figure 13].

Al-Shijbi et al. (2018) evaluated the seismic hazard level [Figure 14], in Erbil city expected PGA in the range of $250-300 \mathrm{~cm} / \mathrm{s}^{2}(0.25-0.3 \mathrm{~g})$ for a 475 year return period and $420-500 \mathrm{~cm} / \mathrm{s}^{2}(0.42-0.51 \mathrm{~g})$ for a 2475 year return period. 
Table 2: PGA value (in units of [g]) for Erbil city, on rock site class, approved by various codes and authors

\begin{tabular}{|c|c|c|c|c|}
\hline Reference study & Earthquake data time span & Return period & \multicolumn{2}{|c|}{ PGA (g) } \\
\hline ISC 1989 (1988) & Dependent events 859-1986 & 475 & $0.075-0.125$ & $0.09 \sim Z$ factor \\
\hline ISC (1997) & & 475 & 0.07 & $0.07 \sim Z$ factor \\
\hline UBC (1997) & & 475 & $0.2-0.3$ & $0.3 \sim Z$ factor \\
\hline GSHAP (1999) & & 475 & $0.24-0.32$ & 0.32 \\
\hline WHO (WHO, 2010) & $\overline{-}$ & 475 & $0.24-0.4$ & 0.4 \\
\hline Al-Sinawi (2006) & Dependent events 1900-1988 & 100 & $0.5-0.6$ & 0.5 \\
\hline Yaseen et al. (2014) & Proposed & & $0.25-0.4$ & 0.4 \\
\hline Hosseini et al. (2014b) & Independent events 1900-2014 & 475 & $0.24-0.26$ & 0.25 \\
\hline \multirow[t]{2}{*}{ Onur et al. (2016) } & Dependent events 1900-2009 & 475 & 0.222 & 0.222 \\
\hline & & 2475 & $0.3-0.4$ & 0.4 \\
\hline Said and Farman (2018a) & Independent events 1900 to April 2016 & 2475 & $0.3-0.4$ & 0.4 \\
\hline \multirow[t]{2}{*}{ Said and Farman (2018b) } & Independent events 1900 to December 2017 & 475 & $0.2-0.25$ & 0.22 \\
\hline & & 2475 & $0.4-0.45$ & 0.42 \\
\hline \multirow[t]{2}{*}{ Al-Shijbi et al. (2018) } & Events 1900-2015 & 475 & $0.25-0.3$ & 0.25 \\
\hline & & 2475 & $0.42-0.51$ & 0.45 \\
\hline
\end{tabular}

PGA: Peak ground acceleration, WHO: World Health Organization, Global Seismic Hazard Assessment Program

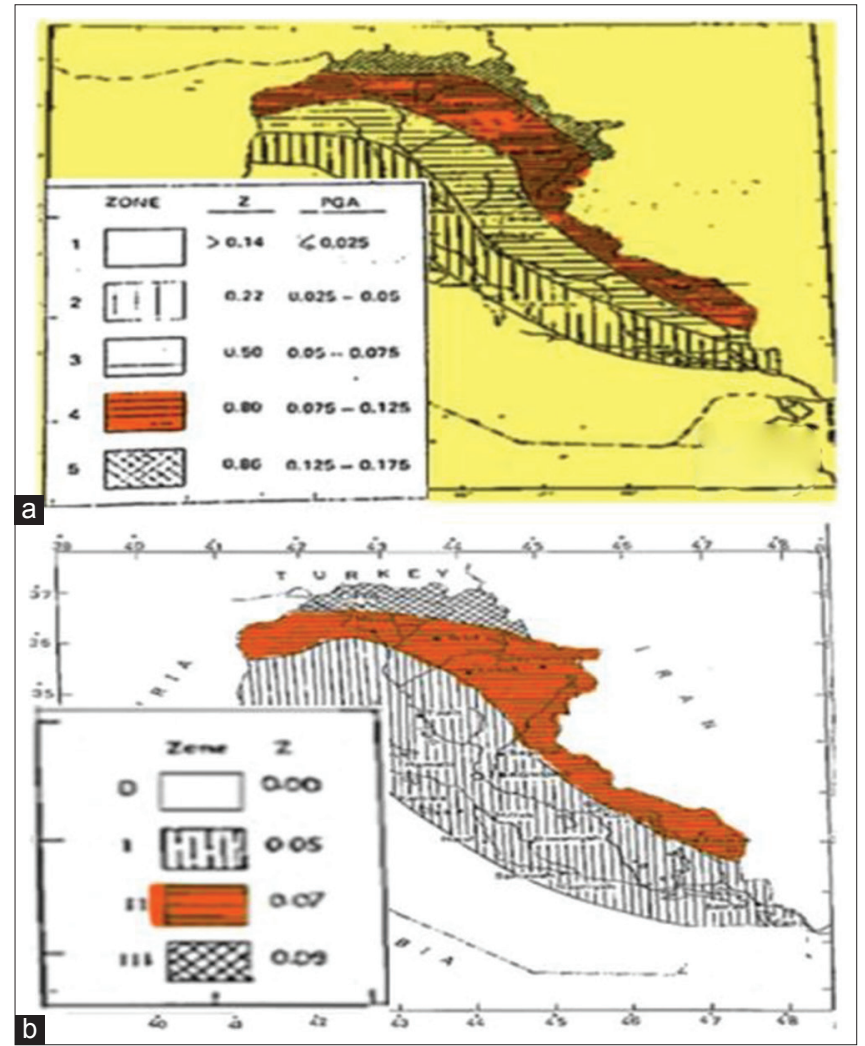

Figure 8: Iraqi seismic codes (a) seismic map 1988 (Mahmood et al., 1988), (b) seismic map 1993-1997 (Code 2/1997, 1997)

The summary of the previous SHA [Table 2] indicates that the PGA according to the WHO, GSHAP, and UBC code is identified by the value $>0.3 \mathrm{~g}$ for 475 years return period, while according to national PSHA studies in Iraq and PSHA for Arabian plate is identified by $0.4 \mathrm{~g}$ for $2 \%$ probability of exceedance in 50 years $(2475$ years return period) and estimated PGA to be $0.25 \mathrm{~g}$ for $10 \%$ likelihood

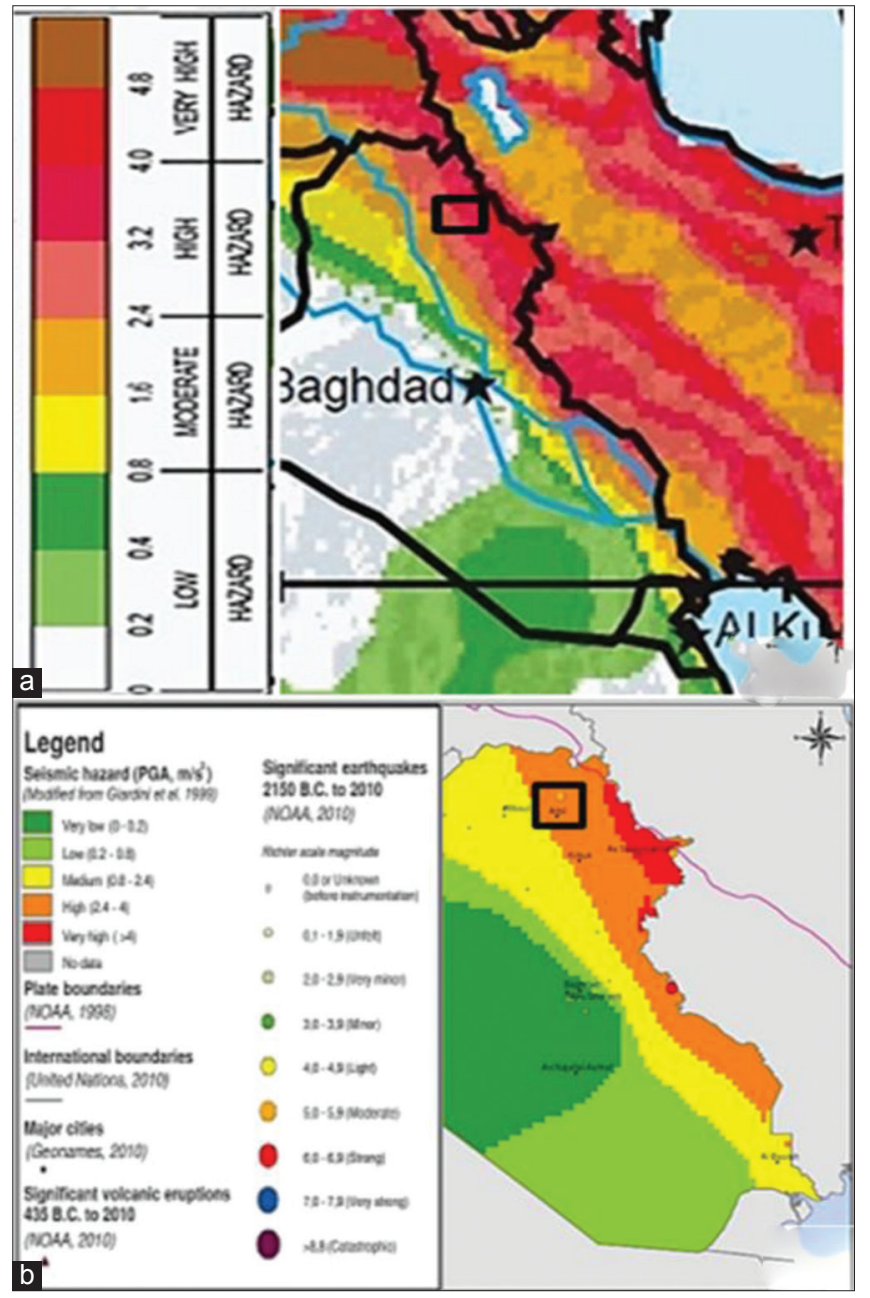

Figure 9: Peak ground acceleration $\left(\mathrm{m} / \mathrm{s}^{2}\right)$ map of rock with a $10 \%$ probability of exceedance in 50 years $(475$ - year return period): (a) Global Seismic Hazard Assessment Program (Grünthal et al., 1999) (b) World Health Organization (World Health Organization, 2010) 


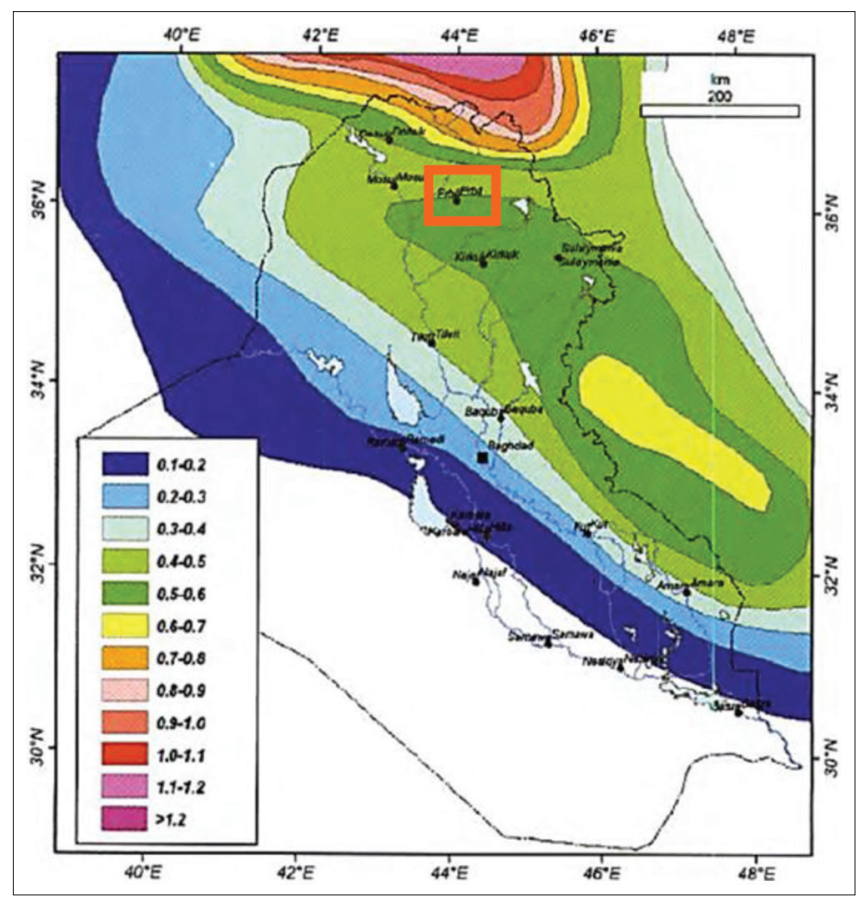

Figure 10: Seismic acceleration map (g) for 100-year return period (Al-Sinawi, 2006)

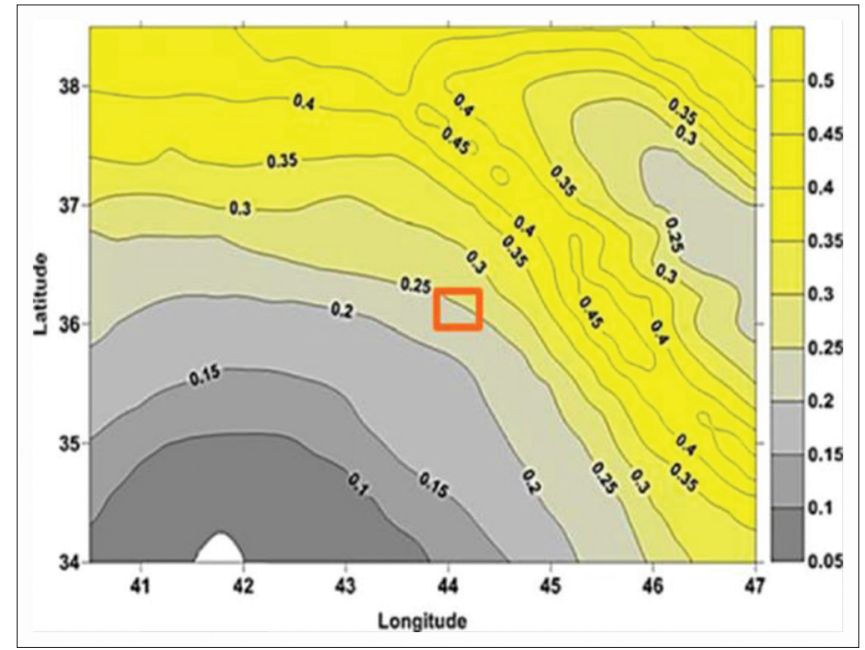

Figure 11: Seismic acceleration map of Kurdistan Region peak ground acceleration (g) for a 475-years return period (Hosseini et al., 2014b)

of exceedance in 50 years (475 years return period), in a term of $5 \%$ damped at bedrock condition.

\section{PROPOSED RESPONSE SPECTRUM IN ERBIL CITY}

According to the updated codes of practice, response spectrum is an important parameter in the structural analysis. In this study, Unified hazard spectrum (UHS) is calculated from the spreadsheet adopted by Sayhan in PEER research center (PEER, 2018), and the required parameters are taken from the review of seismology and

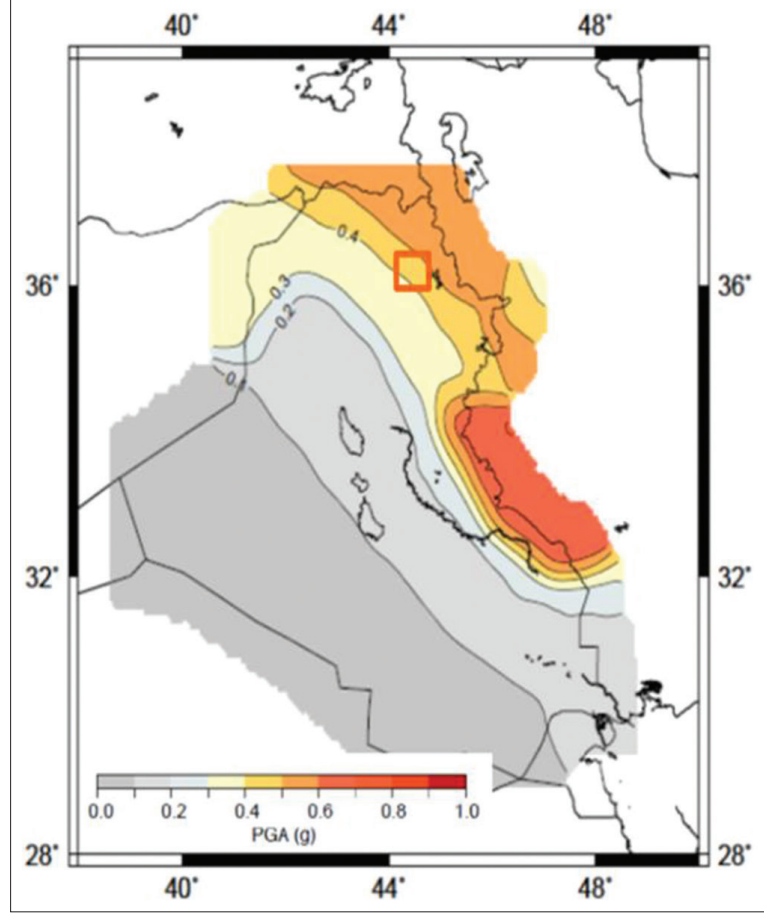

Figure 12: Probabilistic seismic hazard analysis in a term peak ground acceleration in Iraqi map (g) for a 2475-years return period (Onur et al., 2016)

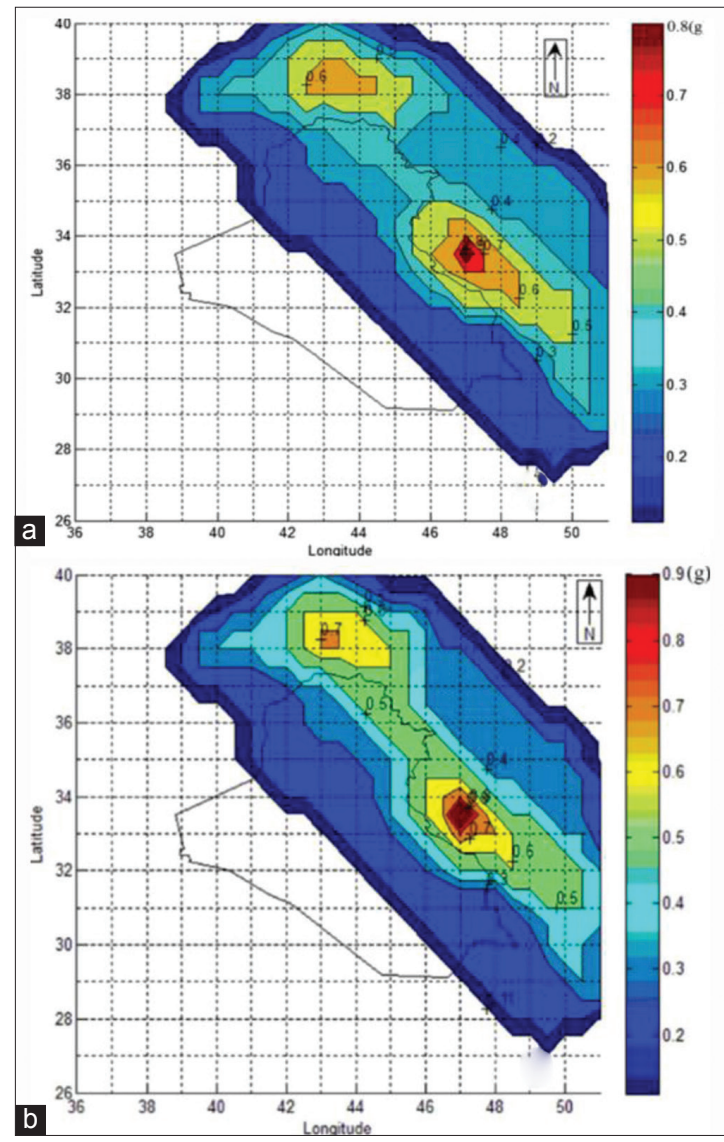

Figure 13: Probabilistic seismic hazard analysis for Iraqi map in a term (a) peak ground acceleration (PGA) and (b) updated PGA for a return period of 2475 years on rock site Class (g) (Said and Farman, 2018a; 2018b) 
Table 3: Response spectral acceleration Ss and S1 (g) approved for Erbil city by various studies

\begin{tabular}{llllcc}
\hline Reference study & Method & GMPE & Site class & \multicolumn{2}{c}{ Response spectral acceleration (g) } \\
\cline { 4 - 6 } & & & Ss & S1 \\
\hline Yaseen et al. (2014) & Proposed & & Rock B & 1 & 0.6 \\
Onur et al. (2016) & PSHA & ASK14, BSSA14, CB14, and CY14 & Rock B & 0.51 & 0.4 \\
Said and Farman (2018a) & PSHA & Akkar et al. and Booe et al. 14 (AB14) & Rock B & 0.66 & 0.13 \\
Said and Farman (2018b) & PSHA & & Rock B & 0.71 & 0.29 \\
Al-Shijbi et al. (2018) & PSHA & Zhao et al., AB10, CY08 & Rock B & 1.1 & 0.35 \\
This study & Poposed (UHS) & ASK14, BSSA14, CB14, and CY14 & Soil D & 1 & 0.21 \\
\hline
\end{tabular}

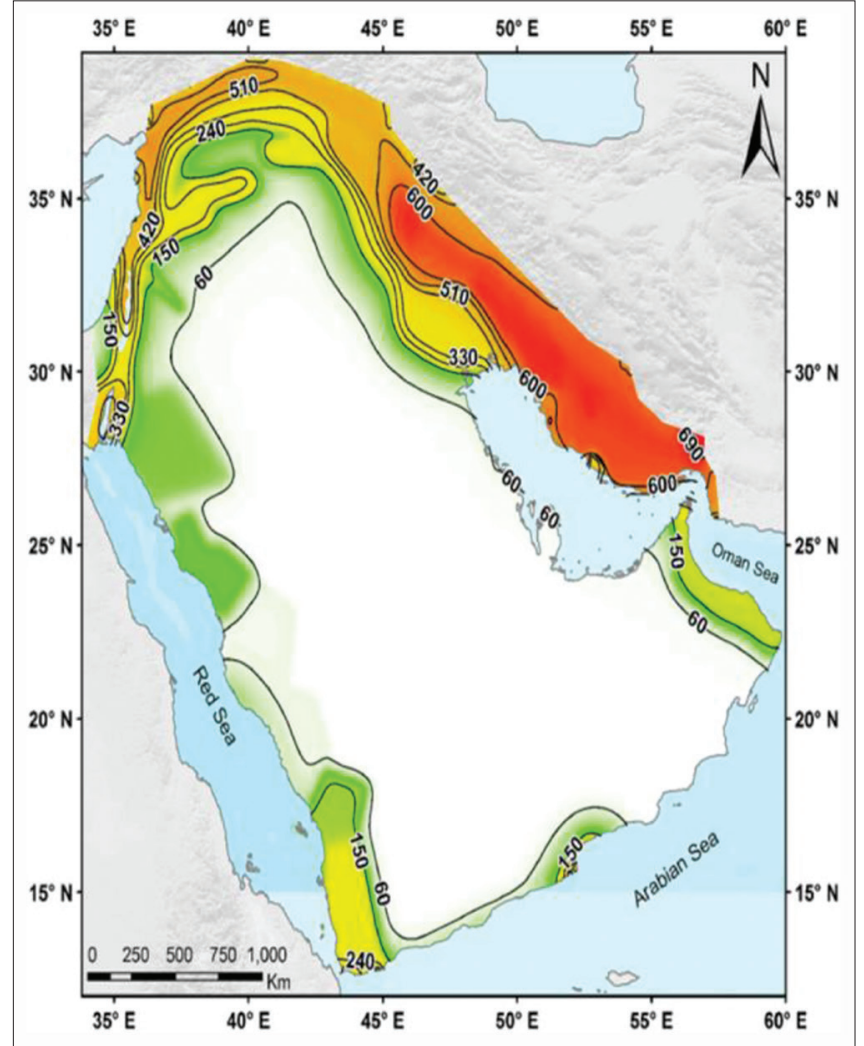

Figure 14: Probabilistic seismic hazard in a term of peak ground acceleration in the Arabian plate for the return period of 2475 years developed by Al-Shijbi et al., 2018

geology. For example, PGA is $0.4 \mathrm{~g}$ for the 2475 years return period, site class is type $\mathrm{D}$, and $\mathrm{Mw}$ is between 6 and 7.5, focal depth $(\mathrm{km})$ smaller than 50, normal (Strikeslip) fault, and the other information about the distances and depths assumed based on the PGA and the default of the program. Four equal weight $(0.25)$ of ground motion prediction equation model (GMPE) is used: Abrahamson and Silva and Kamai 2014 (ASK14), Boore and Stewart and Seyhan and Atkinson (BSSA14), Campbell and Bozorgnia (CB14), and Chiou and Youngs 2014 (CY14) for a standard deviation (SD) is $1 \%$ and damping ratio $5 \%$.

The result of the GMPE, median value, and median value with Sta. dev. is represented in Figure 15. The comparison

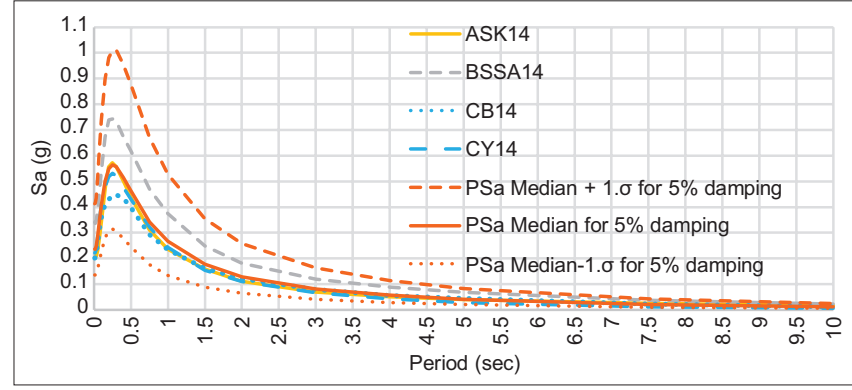

Figure 15: Proposed spectral acceleration for standard deviation $1 \%$, damping ratio $5 \%$, and soil site Class D

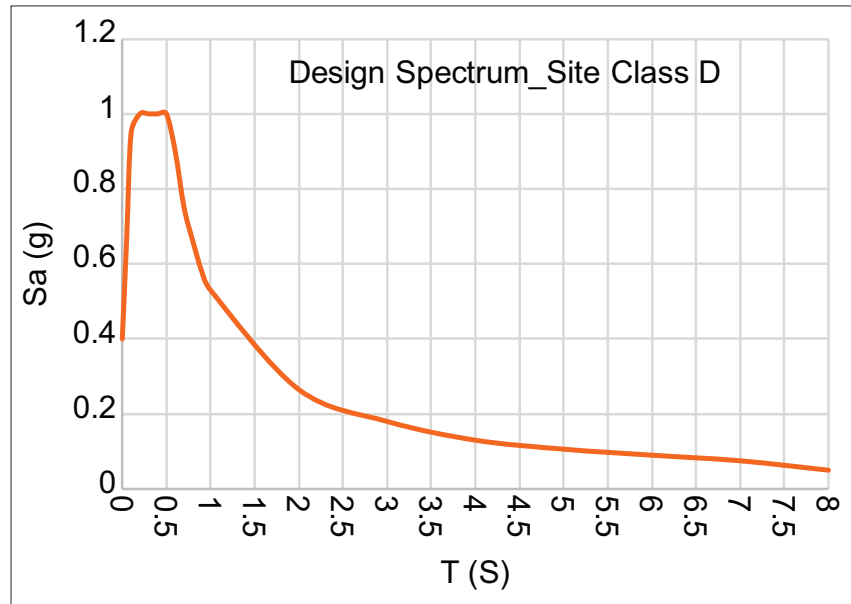

Figure 16: Erbil city design response spectrum (site Class D)

between the response spectrum proposed in this study and in the literature is shown in Table 3. According to ASCE (ASCE07-10) code, design response spectrum graph for Erbil city is depicted in Figure 16.

\section{CONCLUSION}

Erbil city experiences from the Zagros and Taurus Mountains. Historically, at the location near Erbil city experienced a moderate earthquake with $\mathrm{Mw}$ is 5.5 , in recent years, Erbil city experienced an increase in seismic activity. In this study, the seismic characteristics of Erbil city reviewed by focusing on geology and tectonic setting, 
seismicity, and a previous hazard assessment. The study concluded that:

1. At the tectonic level, Erbil city is positioned at the north corner of the Arabian plate and classified by an outer platform of the LFZ in the location of WZFTB

2. Geologically, Erbil city is covered by Quaternary (fluvial sediments) and soil dynamic properties classified by soil site Class D

3. Seismicity and seismic source are characterized by strike-slip (normal) fault, the majority of the earthquakes exhibit at the shallow crustal. Based on the facts of seismology and highly predicting the occurrence of destructive earthquakes in Erbil city, the maximum expected earthquake magnitude in Erbil city can be identified between Mw 6 and 7.5, based on the active parameters of GR

4. Through the reviewing of modifying the seismic hazard map for the location where Erbil city located, it was concluded that the PGA value has been updated in the city, the recommended design PGA evaluated with a range of $0.25 \mathrm{~g}$ for $10 \%$ likelihood of exceedance in 50 years (475 years return period), and $0.4 \mathrm{~g}$ for $2 \%$ probability of exceedance in 50 years (2475 years return period), in a term of $5 \%$ damped at bedrock condition. Although, according to the previous codes is evaluated with a PGA $>0.3 \mathrm{~g}$ for 475 years return period

5. Based on the seismic characteristics and critical parameters, spectral acceleration $(\mathrm{Sa})$ is proposed and then compared with $\mathrm{Sa}$ in the literature. In Erbil city, $\mathrm{Sa}$ at $\mathrm{S}_{\mathrm{s}}$ and $\mathrm{S}_{1}$ obtained to be $1 \mathrm{~g}$ and $0.53 \mathrm{~g}$, for the site Class D.

\section{ACKNOWLEDGMENT}

The aurthors would like to thank Dr. Abdulhameed Abdullah Yaseen from the University of Duhok, for their writing insightful comments, notes, and advice.

\section{REFERENCES}

Abdulnaby, W., H. Mahdi, H. Al-Shukri and N. M. Numan. 2014a. Stress patterns in Northern Iraq and surrounding regions from formal stress inversion of earthquake focal mechanism solutions. Pure Appl. Geophys. 171: 2137-2153.

Abdulnaby, W., H. Mahdi, N. M. Numan and H. Al-Shukri. 2014b. Seismotectonics of the Bitlis-Zagros fold and thrust belt in Northern Iraq and surrounding regions from moment tensor analysis. Pure Appl. Geophys. 171: 1237-1250.

Alakaam, I. S. and Z. I. Hussain. 2016. Identifying the risks of earthquakes in Erbil Governorate, using the technology of geographic information systems, (Arabic Language). J. Coll. Educ: $315-342$.

Al-Shijbi, Y., I. El-Hussain, A. Deif, A. Al-Kalbani and A. M. Mohamed. 2018. Probabilistic seismic Hazard assessment for the Arabian
Peninsula. Pure Appl. Geophys. 176(1): 1-28.

Al-Sinawi, S. A. 2006. Seismicity. In: Jassim, S. Z. and J. C. Goff, editors. Geology of Iraq. Dolin Moravian Museum, Prague, Brno. p84-90.

Ameer, A. S., M. L. Sharma, H. R. Wason and S. A. Alsinawi. 2005. Probabilistic seismic Hazard assessment for Iraq using complete earthquake catalogue files. Pure Appl. Geophys. 162: 951-966.

ASCE/ASCE07-10. 2013. Minimum Design Loads for Buildings and Other Structures. $7^{\text {th }}$ ed. American Society of Civil Engineers, Reston, VA.

Code 2/1997. 1997. Iraqi Seismic Code Requirements for Buildings. Building Research Centre, Baghdad, Iraq.

Code UBC. 1997. International Conference of Building Officials. Uniform Building Code, Whittier, California.

Draft/Code-16. 2016. Draft of Iraqi Seismic Code. Submitted to Central Organization for Standardization and Quality Control COSQC, Iraq, Baghdad.

El-Hussain, I., Y. Al-Shijbi, A. Deif, A. M. E. Mohamed and M. Ezzelarab. 2018. Developing a seismic source model for the Arabian Plate. Arab. J. Geosci. 11: 435.

EMSC. 2018. M6.3 \#earthquake strikes $163 \mathrm{~km} \mathrm{NE}$ of \#Baghdad (\#lraq). Available from: https://www.twitter.com/LastQuake/ status/1066736920301047810. [Last accessed on 2019 Apr 11].

EMSC. 2019. M5.7 \#earthquake strikes $133 \mathrm{~km} \mathrm{NE}$ of \#Baghdad (\#lraq). Available from: https://www.twitter.com/LastQuake/ status/1081912787339804674. [Last accessed on 2019 Apr 11].

Fouad, S. F. 2015. Tectonic map of Iraq, scale 1: 1000 000, 2012. Iraqi Bull. Geol. Min. 11: 1-7.

Fouad, S. F. and V. K. Sissakian. 2015. Geological map of IRAQ, scale 1: 1000 000, 2012. Iraqi Bull. Geol. Min. 11: 9-16.

Ghalib, H. A. A. and G. I. Aleqabi. 2016. Seismicity, velocity structure and tectonics of the Arabian plate. J. Zankoy. Sulaymani. 18-1(Part-A): 481-497.

Grünthal, G., C. Bosse, S. Sellami, D. Mayer-Rosa and D. Giardini. 1999. Compilation of the GSHAP regional seismic Hazard for Europe, Africa and the Middle East. Ann. Geofis. 42(6): 12151223.

Hosseini, R., G. R. Lashkaripour, N. H. Moghaddas and M. Ghafoori. 2014a. Proposed seismotectonic provinces for Kurdistan regionNorth-Eastern Iraq. Int. J. Curr. Life Sci. 4(11): 9060-9066.

Hosseini, R., G. R. Lashkaripour, N. H. Moghaddas and M. Ghafoori. 2014b. Probabilistic Seismic Hazard for Kurdistan Region-NE Iraq. $2^{\text {nd }}$ International Congress on Structure, Architecture and Urban Development, 16-18, Tabriz, Iran.

IMOS. 2018. Iraqi Meteorological Organization and Seismology. Available from: http://www.meteoseism.gov.iq.com. [Last accessed on 2019 Apr 11].

Jassim, S. Z. and Goff, J. C., editors. 2006. Geology of Iraq. $1^{\text {st }}$ ed. Dolin , Moravian Museum, Prague, Brno.

Kramer, S. L. 1996. Geotechnical earthquake engineering. In: Prentice-hall International Series in Civil Engineering and Engineering Mechanics. Prentice-Hall, New Jersey.

Mahmood, D., S. Khalifa, S. L. Jordanovski and D. Dojcinovski. 1988. Seismic Hazard Evaluation and Seismic Zoning Maps of Iraq. Building Research Center, Baghdad.

Mohammed, Q. S. A. and M. A. Abdulrassol. 2017. Database of dynamic soil properties for most Iraq soils. Am. Sci. Res. J. Eng. Technol. Sci. 37: 230-254.

Onur, T., R. Gok, W. Abdulnaby, A. M. Shakir, H. Mahdi, N. Numan, H. Al-Shukri, H. K. Chlaib, T. H. Ameen and N. A. Abd. 2016. Probabilistic Seismic Hazard Assessment for Iraq. Lawrence 
Livermore National Lab. (LLNL), Livermore, CA (United States).

PEER. 2018. Pacific Earthquake Engineering Research Center, NGA Database. Available from: https://www.ngawest2.berkeley.edu/ nga. [Last accessed on 2018 Dec 10].

Said, A. I. and M. S. Farman. 2018a. Re-evaluations of seismic Hazard of Iraq. Arab. J. Geosci. 11: 279.

Said, A. I. and M. S. Farman. 2018b. Updated probabilistic seismic Hazard assessment for Iraq/2018. Civ. Eng. J. 4: 1610-1628.

USGS. 2017. USGS Event Page, U.S Geological Survey, Magnitude 7.3 Earthquake Iran/Iraq Border. Available form: https://www. usgs.gov/news/magnitude-73-earthquake-iraniraq-border. [Last accessed on 2018 Sep 12].

WHO. 2010. Iraq-seismic Hazard Distribution Map. Scribd. Available from: https://www.scribd.com/document/139326454/ Iraq-Seismic-Hazard-Distribution-Map. [Last accessed on 2018 Sep 28].

Yaseen, A. A., D. Begg and N. Nanos. 2014. Time History Analysis of Existing Buildings in the Kurdistan Region of Iraq. Presented at the $1^{\text {st }}$ International Engineering Conference on Developments in Civil and Computer Engineering Applications (IEC2014, Kurdistan Regional Government (KRG) of Iraq, Erbil. 